\title{
DETERMINANTS OF LIFE SATISFACTION AMONG FEMALE-HEADED HOUSEHOLDS IN MALAYSIA
}

\author{
Mohamad Fazli Sabri* \\ Universiti Putra Malaysia \\ Thinagaran Moga Dass \\ Universiti Putra Malaysia \\ Nik Ahmad Sufian Burhan \\ Universiti Putra Malaysia \\ Husniyah Abdul Rahim @ Abdul Wahab \\ Universiti Putra Malaysia \\ Rusitha Wijekoon \\ Universiti Putra Malaysia \\ Megawati Simanjuntak \\ Bogor Agricultural University
}

\begin{abstract}
Female-headed households in Malaysia have been a financially vulnerable community in the society where their life satisfaction becomes a question. Therefore, this study aims to determine the factors affecting life satisfaction among female-headed households in Malaysia. A total of 527 respondents who are single, divorced, separated or widowed women, with children in the home including those on public assistance participated in this study which adapted a multi-stage sampling method using self-administered questionnaire. The results show that locus of control, religiosity, financial capability, and financial vulnerability have positive significant relationships with life satisfaction. The multiple regressions show that locus of control, religiosity, financial capability, and financial vulnerability are significant determinants of life satisfaction among female-headed household in Malaysia. More knowledge, and enhancement through financial workshops could be helpful to empower female-headed household on the use of modern financial instruments. Hence, able to increase financial capability and reduce financial vulnerability of female-headed households in Malaysia towards a better life satisfaction.
\end{abstract}

Keywords: Financial Capability, Financial Vulnerability, Life Satisfaction, Locus of Control, Religiosity.

Received: 3 September 2019

Accepted: 30 December 2020

https://doi.org/10.33736/ijbs.3175.2021

\footnotetext{
* Corresponding author: Institute for Social Science Studies, Universiti Putra Malaysia, Putra Infoport, 43400 UPM Serdang, Selangor, Malaysia; Faculty of Human Ecology, Universiti Putra Malaysia; Email: fazli@upm.edu.my
} 


\section{INTRODUCTION}

The final phase of Vision 2020 which is driven by the $11^{\text {th }}$ Malaysia Plan (2016-2020) emphasizes on the requirement for more noteworthy inclusiveness, particularly in increasing the living qualities of the bottom $40 \%$ of the population by income (B40), decreasing the income and infrastructural gaps between the rich and the poor people, and expanding the contribution of women in the economy (OECD, 2016). In accomplishing this, the fundamental approach is to enhance the annual household income of the B40 category from Malaysian Ringgit (RM) 2,537 in 2014 to RM 5,270 in 2020 (EPU, 2015) by increasing the financial interest of urban family units via human capital advancement, income-generating exercises, and micro-enterprise supporting programmes in lifting the average income of the individuals, and in this manner their well-being.

Increasing living expenses are one of the significant variables contributing to the expanding rate of working women in Malaysia along with the effect of globalization which has created greater job opportunities for females in the globalised manufacturing industries, and in the growing service economy. Moreover, such circumstances are progressively vulnerable to women who are the leader of the families, who are distinguished as female-headed households or generally recognized as single mothers. The Ministry of Women, Family and Community Development (KPWKM) has stated that there are 235,000 single mothers in Malaysia who fit the following definition: "(1) women who are divorced, and have children; (2) women are married but their husbands are disabled, and unable to support the family; (3) females who are not married but have adopted or illegitimate youngster" (KPWKM, 2014).

The challenges confronted by female-headed household as the leader of the family are difficult, because they need to hold up under double duties, "where they are not only breadwinners, but also the managers, and educators of their children" (Faizah \& Azian, 2013). Besides that, single mothers are constantly linked with poverty, and are opened to financial strains (Klasen, Lechtenfeld, \& Povel, 2011). Furthermore, Faizah and Azian (2013) in their research revealed that majority of the Malaysian single mothers do not receive satisfactory support from the government, despite how $75 \%$ of the Female-headed households are yet living beneath the poverty line or considered as B40 category.

Moreover, single mothers are more prone to encounter various misfortunes, family responsibilities, and economic hardship, and rising demands of childcare contrasted with married women. Other than that, they are bound to work extended hours, have less steady social networks, get less emotional, and tangible support, facing social stigmas, and isolations which direct to disappointment, and loneliness (Faizah \& Azian, 2013), and greater dimensions of stress, and depression contrasted with married women (Hashim, Azmawati, \& Endut, 2015). Such hardships direct them to confront lower life satisfaction (Lucas, 2005), psychological stress (Booth \& Amato, 1991), and account frequent medical visits (Canady \& Broman, 2003), which will gradually influence productivity, and outcomes in life. Furthermore, single mothers are probably going to endure emotional distress and depression contrasted with married women (Afifi, Cox, \& Enns, 2006), and their youngsters have a tendency to develop antisocial behaviour, with some engaged in social issues like vandalism, gangsterism, and drug abuse (Baharudin, Krauss, Yacoob, \& Pei, 2011). 
Prevailing literature on the personality of Malaysian single mothers largely focussed on profiling, fate, emotion, and cultural practices in connection with well-being, and life satisfaction (Faizah \& Azian, 2013), and there is a necessity in investigating different factors of personality like religiosity, positive optimal functioning, acceptance of life, and life experience to examine how these factors influence life satisfaction of single mothers in the Malaysian setting. Extraordinary occasions for example, divorce, abandonment by a husband, the death of a husband, and sickly or disabled life partners likewise has expanded the financial vulnerability among single mothers (Ahmad \& Sabri, 2015). In addition to that single mothers often run out of money, and seldom make savings due to difficulties in finding a job as they have low education, increased age, and less experience (Ishak, Selvaratnam, \& Idris, 2009). Further, the impact of increasing expenses of living largely affects single mothers as it will make them unfit to set aside cash or invest, as the revenue is just adequate for their living. A financially vulnerable single mothers cannot afford their monthly expenses, and to balance the budget, delays in service charge payments, troubles in shopping for necessities or paying the rent will later on drag them into indebtedness. Being financially vulnerable certainly makes people financially incapable, leading to lower life satisfaction (Chou \& Chi, 2002).

In summary, previous research revealed that single mothers have been a vulnerable category confronting numerous difficulties to assist their dependents. Women are one of the pillars in a nation's development. Therefore, it is important to examine the elements influencing the life satisfaction of single mothers in Malaysia, particularly financial aspects, to gain a better economic status to cope with rising living expenses and simultaneously improve their life satisfaction. Therefore, the current research intends to determine how factors like locus of control, religiosity, financial vulnerability, and financial capability affect and predict life satisfaction of single mothers in Malaysian context.

\section{LITERATURE REVIEW}

\section{$2.1 \quad$ Female-Headed Household}

According to Ahmad and Sabri (2015), 61\% of the Malaysian female-headed households only possessed secondary level of education as the highest education level, while $12.9 \%$ of them did not attend school. Correspondingly, Ishak et al., (2009) indicated that $21.8 \%$ of the female-headed households were not employed and depend on government welfare and part time jobs for survival. Moreover, $45 \%$ and $17 \%$ of them have to the support school-going children, and unemployed children respectively, and $40 \%$ of them also have income less than RM 1,000 per month (Faizah \& Azian, 2013), and 83.9\% of them did not receive any welfare (Ahmad \& Sabri, 2015).

Generally, it is reported that many female-headed households also suffer from emotional stress, loneliness, and emptiness due to lack of a life partner to share their ups and downs (Hamid, Mottan, \& Tyng, 2010). Besides that, social stigma also adds to the emotional stress of single mothers, as the stigma leads them to frustration, and loneliness due to a lack of social support compared to wives with husbands. Moreover, single mothers are always linked with higher levels of poverty. The poverty among female-headed households leads to consequences such as financial stress (Choi, 2009), frequent borrowing behaviour (Mahal, Seshu, Mane, \& Lal, 2012), with some even leading to bankruptcy (Aldana \& Liljenquist, 1998). 


\subsection{Financial Capability}

Financial capability is a person's ability to oversee and assume responsibility for their finances (Taylor, 2011). It is determined by financial behaviours and a specific dimension of financial literacy (Taylor, Jenkins, \& Sacker, 2009). According to Atkinson, McKay, Kempson, and Collard (2006), financial capability integrates skills, knowledge, and behaviour in five areas: making ends meet, planning ahead, keeping track, choosing products, and staying informed. Further, high level of financial capability was linked with lower depression, greater life satisfaction, higher selfesteem, higher locus of control, and a less malaise (Melhuish, Belsky, \& Malin, 2008).

In the Malaysian context, Sabri and Zakaria (2015) investigated financial well-being, financial capability, and the kind of attitudes youthful Malaysian workers towards the money. In this study they found that $73.3 \%$ of the respondents possessed a moderate dimension of financial capability while only $24.2 \%$ have a greater dimension of financial capability. Besides, financial capability was the second indicator of financial well-being among youthful employees after financial strains. Moreover, another study conducted by Sabri, Mokhtar, Ho, Anthony, and Wijekoon (2020) studied the impact of sociodemographic characteristics on the four domains of financial capability, namely planning ahead, managing money, choosing products, and staying informed, and revealed that gender posed a significant effect on the domains of planning ahead and staying informed.

\subsection{Financial Vulnerability}

The term financial vulnerability is "the cognitive, emotional, and behavioural responses to the experience of economic hardship that happens when real costs surpass income, and one is not able to meet their financial responsibilities" (Starkey, Keane, Terry, Marx, \& Ricci, 2013, p. 90). Several studies indicated that financial vulnerability has an impact on life satisfaction and wellbeing. Financial vulnerability has been identified as a key factor of psychological distress (Mirowsky \& Ross, 2004), and single mothers are impacted by economic strains due to their sole responsibility for the households' financial needs (Pollmann-schult, 2016). Further, financial vulnerability has a moderate association with depression, and life satisfaction among the young mothers, and it is the strongest predictor of life satisfaction (Melhuish et al., 2008).

Slightly more than half $(51.7 \%)$ of Malaysians were reported to demonstrate moderate levels of financial vulnerability, $15.2 \%$ were highly financially vulnerable, and $33.1 \%$ were possessed low financial vulnerability (Loke, 2017). A study in Kuala Lumpur in determining the association between financial strain, and personal well-being among 1,064 individuals from urban poor communities has revealed that almost half of the respondents (50.3\%) demonstrated high financial strain, and it is the second determinant of personal well-being after financial behaviour (Moga Dass \& Sabri, 2017). In another study, money attitude was observed as a mediating variable between personal finance, and financial vulnerability (Sabri, Abdullah, Zenhendel \& Ahmad, 2017).

\subsection{Personality}

Researchers started to focus on the relation between personality and subjective well-being after scholars realized that subjective well-being is frequently, strongly linked with stable personality traits. Personality traits were found to clarify $19 \%$ of variance in life satisfaction in Iranian 
employed women. (Hosseinkhanzadeh \& Taher, 2013). This study focused on two domains of personality which are locus of control and religiosity.

\subsubsection{Locus of Control}

The locus of control estimates an individual's desires for either the requirement for internal or external control of reinforcement as an aspect of personality (Rotter, 1966). In particular, it signifies "to the extent to which people believe they or external factors, such as chance, and powerful others, are in control of the events that influence their lives" (Firth, Mellor, Moore, \& Loquet, 2004, p. 175). Meanwhile, people with an external locus of control scored high scores, and trust that their actions in life are commonly outside of their control (Rotter, 1966).

A comparative study between China, and South Africa on the linkage between locus of control, and well-being indicated that Chinese tend to have an external locus of control, while South Africans have an internal locus of control. A weak negative correlation found between locus of control, and subjective well-being was discovered in the Chinese, and the South African samples respectively. Klonowicz (2001), in attempting to gauge the locus of control as a determining factor of subjective well-being made comparative determinations, presuming that a high internal locus of control identifies with progressively beneficial outcomes. The examinations demonstrate that locus of control has a unique association with well-being.

An investigation on 127 Malaysian females with breast cancer uncovered that they present higher internal locus of control, and lower external locus of control, and experience a higher personal satisfaction, lower rates of depression, and lower anxiety (Sharif, 2017). The author further clarified that women with a lower locus of control felt powerless, and doubted their control over their fate, which leads them to experience greater anxiety, and depression. Furthermore, Faizah and Hashim (2013) showed that an internal locus of control is most dominating among single mothers in Johor contrasted with an external locus of control. This investigation further demonstrated that there was a noteworthy association between family problems, economic problems, community support, social stigma, as well as psychological, and emotional issues with the locus of control among female-headed households.

\subsubsection{Religiosity}

Schaffer (1996) characterizes religiosity as the level of participation, or involvement, or faith towards the practices, and convictions of a religion. As per the Islamic view, Al-Goaib (2003) characterizes religiosity as the dedication, and devotion to the experimental, and hypothetical base of Islam, through which Muslims satisfy the privileges of God, ensure the privileges of others, pursue the heavenly commandments, restrain from wrong deeds, and worship.

Many studies report that religiosity is positively correlated to well-being. For instance, religiosity forecasts significance, and life fulfillment in Algerian Muslim students, besides enjoying higher social well-being (Tiliouine \& Belgoumidi, 2009). In addition, Abdel-Khalek (2010) revealed that religiosity was correlated with better health, and well-being, and less anxiety among Muslim Kuwaiti adolescents. Williams and Sternthal (2007) revealed that individuals with higher religiosity are healthier and have higher life expectancies. A contextual analysis among 315 Muslim women academicians in Malaysia showed that there is a significant positive correlation 
between personal well-being, and religiosity, beliefs, worship, and prayers. The results also suggested that there are desirable increases in well-being for every unit increment in religiosity (Achour, Grine, Mohd Nor, \& Yusoff, 2015).

\subsection{Life Satisfaction}

Subjective well-being reflects how individuals can encounter a set of circumstances as just as important as the conditions themselves, and that individuals are the best adjudicators of how their own lives are going on (OECD, 2011). Subjective well-being is an indicator of well-being which is divided into two, namely, life satisfaction, and balance. Life satisfaction is defined as a reflective evaluation of how things are going in one's own life (OECD, 2011).

Studies across countries discovered that marriage increases happiness. Higher subjective wellbeing is found within married people compared to singles, divorced, separated or widowed peoples, as marriage is a source of self-esteem, support, and companionship (Frey \& Stutzer 2002). Life in a female-headed household is commonly associated with financial stress, and psychological stress, which affects their life satisfaction (Pollmann-schult, 2016). In Pakistan, the life satisfaction of married, and unmarried women scored higher than divorced women, while widowed women were reported to possess higher satisfaction levels compared to divorced women (Suhail \& Chaudhry, 2004). A Scandinavian (North Europe) study on determining the predictors of happiness among female-headed households, and partnered mothers stated that female-headed households possesses lower life satisfaction (Bull \& Mittelmark, 2009). These global studies indicate in general that female-headed households have lower life satisfaction compared to married mothers.

Several studies on the life satisfaction of women have been done in Malaysia. For instance, Wan, Jaccard, and Ramey (1996) in their research compared the life satisfaction between female-headed households, married mothers, and married fathers, and found external social support to be a significant indicator of life satisfaction among female-headed households. Furthermore, previous studies on female-headed households paid attention on the job stress, financial stress, family conflict, health, and coping approaches on life satisfaction. But, the current research attempts to analyse the relationship between the variables mentioned above to pave a way in strengthening the financial vulnerability, financial capability, and personality of single mothers to enhance their life satisfaction.

The following hypotheses are developed based on the above literature;

$H_{a}$ 1: There is a significant relationship between locus of control, and life satisfaction among female-headed households in Malaysia.

$H_{a}$ 2: There is a significant positive relationship between religiosity, and life satisfaction among female-headed households in Malaysia.

$H_{a}$ 3: There is a significant positive relationship between financial capability, and life satisfaction among female-headed households in Malaysia.

$H_{a} 4$ : There is a significant positive relationship between financial vulnerability, and life satisfaction among female-headed households in Malaysia. 
$H_{a}$ 5: Locus of control, religiosity, financial capability, and financial vulnerability are significant determinants of life satisfaction among female-headed households in Malaysia.

\section{METHODOLOGY}

\subsection{Data and Sample}

The Multi-stage random sampling method was adopted in this research to collect 600 samples of single mothers from five single-mother associations in Malaysia, which are divided by zones of Northern, Eastern, Southern, Central of the Peninsular Malaysia, and East Malaysia. Peninsular Malaysia, which consists of 12 states divided into four zones which are the North (Kedah, Penang, Perlis, \& Perak), East (Pahang, Terengganu, \& Kelantan), South (Melaka, \& Johor), and Central (Kuala Lumpur, Selangor, \& Negeri Sembilan) zones. Meanwhile, East Malaysia consists of Sabah and Sarawak is the fifth zone in this study. The sample included all the female-headed households falling under three criteria, which is described earlier. The second stage one state for each zone was randomly identified. As a result of that five states that were randomly selected from each zone for data collection were Perak (North), Terengganu (East), Melaka (South), Selangor (Central), and Sabah (East Malaysia). Each state aimed at engaging 120 respondents.

At the third stage, one single-mother association was randomly identified for every state chosen based on the association list obtained from the KPWKM, and The Council of Malaysian SingleMother Organizations. Then at the fourth stage, 120 respondents were chosen per association to participate in the research based on the list given by the association. Self-administered questionnaires were distributed to the female-headed households as it can capture information such as income, loans, credit lines, and locus of control, religiosity, financial vulnerability, financial capability, and life satisfaction. The response rate was $87.8 \%$ where 527 out of 600 instruments distributed were used for the analysis of this study while 73 of them were incomplete and rejected due to unresponsive respondents and missing responses.

\subsection{Variables}

The questionnaire has consisted six sections which are; A-demographic facts of the respondents, B- socioeconomic status of the female-headed households, C-personality for locus of control and religiosity, D- financial capability, E- financial vulnerability, and F- life satisfaction of the single mothers.

\subsubsection{Dependent Variable}

Life satisfaction: The life satisfaction items were adapted from The Satisfaction With Life Scale (Diener, Emmons, Larsen, \& Griffin, 1985) which requires the respondents to rate their life satisfaction from Strongly Disagree (1) to Strongly Agree (4). This section asked the respondents on their satisfaction with their life, their life situation, and whether they achieve their aspirations in life. 


\subsubsection{Independent Variables}

Personality: In this study, personality was measured using 18 questions covering two aspects, which are locus of control and religiosity. This part was measured by a five-point frequency scale. The respondents rated their responses based on frequency from never (1) to always (5). The questions were adopted and modified from Pettijohn, Pettijohn, and Sacco (2005) for Locus of Control aspects, and Huber and Huber (2012) for religiosity (See Appendix 1).

Financial Capability: Financial capability was measured with 20 items covering four different domains, which are managing money, choosing products, staying informed, and planning ahead (See appendix). This instrument was used in the Financial Services Authority (FSA) (2006) study. The part was measured by a four-point Likert scale. The respondents rated their responses from Strongly Disagree (1) to Strongly Agree (4).

Financial Vulnerability: Financial Vulnerability was assessed by using 16 statements adapted and modified from the Financial Strain Scale by Aldana and Liljenquist (1998). The respondents rated their responses from Never (1) to Always (5), (See Appendix 1).

\subsection{Analysis}

Based on the analysis, Table 1 displays the Cronbach's Alpha values for both pilot test, and actual data. All the Cronbach's Alpha values for the variables of pilot test are higher than 0.75. The Cronbach's Alpha for all the variables for actual test are higher than the values of pilot test which are more than 0.83 .

Table 1: Reliability Analysis of Scales

\begin{tabular}{lcccc}
\hline \hline Instrument & $\begin{array}{c}\text { Number } \\
\text { of items }\end{array}$ & $\begin{array}{c}\text { Cronbach's Alpha } \\
\text { (Pilot) }(\mathbf{n = 2 7})\end{array}$ & $\begin{array}{c}\text { Number } \\
\text { of items }\end{array}$ & $\begin{array}{c}\text { Cronbach's Alpha } \\
\text { (Actual) (n=527) }\end{array}$ \\
\hline Locus of control & 9 & 0.752 & 9 & 0.838 \\
Religiosity & 10 & 0.768 & 9 & 0.858 \\
Financial capability & 20 & 0.896 & 20 & 0.937 \\
Financial vulnerability & 16 & 0.788 & 16 & 0.917 \\
Life satisfaction & 4 & 0.918 & 4 & 0.852 \\
\hline \hline
\end{tabular}

To analyze the data, the Statistical Package for Social Science version 22.0 (SPSS) was utilized. Descriptive univariate analyses were used to describe patterns of response. The demographic, and socioeconomic profiles of the respondents are described in terms of frequency, mean, percentage, and standard deviation. Pearson Correlation was applied to determine the relationships for bivariate analyses. Finally, multivariate analyses such as multiple regression were implemented to recognize determinants of life satisfaction among Malaysian single mothers. 


\section{RESULTS AND DISCUSSION}

\subsection{Respondent's Sociodemographic Profile}

The respondents' demographic profile is shown in Table 2. Based on the data obtained, majority of the single mothers were above 51 years old $(59.8 \%)$, and the mean age is $53.14(\mathrm{SD}=11.88)$ years. This clearly shows that majority of the Malaysian single mothers will be facing the retirement phase of life. Majority of them (82.1\%) are Bumiputera, and $17.9 \%$ of them are nonBumiputera. Among them, Muslims (95\%), Christians (3.1\%), Buddhists $(0.8 \%)$, Hindus $(0.8 \%)$, and others $(0.4 \%)$ were recorded. Exploring the respondents' educational level, majority of the female-headed households $(55.3 \%)$ have studied up to secondary school, followed by primary levels of education (29.8\%), and $9.5 \%$ of them have tertiary education like diplomas, Bachelors, Masters, and PhDs. Meanwhile, the employment details show that about half of them (50.5\%) are self-employed, followed by $19 \%$ working in the private sector, and $10.6 \%$ as government employees. There are few people $(2.7 \%)$ who are working with family without formal wages, and $11.6 \%$ are categorized as 'others' as they either do not have a permanent job, have retired, are involved in social services, or are relying on husband's pension money. The finding also shows that, $58.9 \%$ of them have deceased husbands, and $32.1 \%$ of them are divorced. Other than that, $5.9 \%$ of them were abandoned by their husband, $1.8 \%$, and $1.3 \%$ of them have spouses with illnesses, and other reasons respectively. It is notable that $74.7 \%$ of the single mothers did not receive any kind of financial aid, and only $24.3 \%$ are receiving it.

Table 2: Respondents' Sociodemographic Profile $(\mathrm{n}=527)$

\begin{tabular}{|c|c|c|c|}
\hline Demographic & Characteristic & $\overline{\mathbf{n}}$ & $\%$ \\
\hline \multirow[t]{4}{*}{ Age (years) } & $<30$ & 22 & 4.1 \\
\hline & $31-40$ & 62 & 11.8 \\
\hline & $41-50$ & 128 & 24.2 \\
\hline & $>51$ & 315 & 59.8 \\
\hline \multirow[t]{2}{*}{ Ethnicity } & Bumiputera & 433 & 82.1 \\
\hline & Non-Bumiputera & 95 & 17.9 \\
\hline \multirow[t]{5}{*}{ Religion } & Islam & 501 & 95.0 \\
\hline & Buddhist & 4 & 0.8 \\
\hline & Hindu & 4 & 0.8 \\
\hline & Christian & 16 & 3.1 \\
\hline & Others & 2 & 0.4 \\
\hline \multirow[t]{4}{*}{ Education level } & No formal education & 28 & 5.4 \\
\hline & Primary school & 157 & 29.8 \\
\hline & Secondary school & 291 & 55.3 \\
\hline & Higher education & 50 & 9.5 \\
\hline \multirow{6}{*}{ Employment sector } & Employer & 30 & 5.7 \\
\hline & Government & 56 & 10.6 \\
\hline & Private & 100 & 19.0 \\
\hline & Self employed & 266 & 50.5 \\
\hline & Family worker without salary & 14 & 2.7 \\
\hline & Others & 61 & 11.6 \\
\hline \multirow{3}{*}{$\begin{array}{l}\text { Reason for being female- } \\
\text { headed household }\end{array}$} & Divorced & 169 & 32.1 \\
\hline & Spouse deceased & 310 & 58.9 \\
\hline & Spouse with illness & 9 & 1.8 \\
\hline
\end{tabular}




\begin{tabular}{llcc} 
& Abandoned by spouse & 31 & 5.9 \\
& Others & 7 & 1.3 \\
Receiving financial aid & Yes & 394 & 74.7 \\
& No & 128 & 24.3 \\
Types of financial aid received & Compensation from ex-husband & 47 & 8.9 \\
& Zakat & 95 & 18.0 \\
& BR1M & 477 & 90.6 \\
& Baitumal & 32 & 6.0 \\
& Aid from relatives & 27 & 5.2 \\
& Bantuan Kanak-kanak $(B K K)$ & 25 & 4.7 \\
& Department of people welfare & 119 & 22.5 \\
& Malaysia & & \\
\hline \hline
\end{tabular}

\subsection{Respondent's Socio-economic Status}

The socio-economic status of the Malaysian single mothers is shown in Table 3. Household incomes below RM 1,500 are categorised as relative poverty, or widely known as mudah miskin in local terms (EPU, 2015). Hence, according to the respondents' income they have divided the into two groups which is vulnerable (income below RM 1,500), and non-vulnerable (income above RM 1,500) grounded on the categorization by EPU of Malaysia (2015) which denotes as relative poverty. About two thirds of the respondents (60.9\%) earn below RM 1,500 monthly, falling into the category of relative poverty, and $39.1 \%$ of them earn above RM 1,500 monthly. According to the $11^{\text {th }}$ Malaysian Plan, the mean income of Malaysian is RM 6,141, and the mean income for the B40 community is RM 3,000 (EPU, 2015). This scenario shows that almost more than half of the Malaysian single mothers are part of B40.

Observing the percentage of savings, slightly more than half $(52.3 \%)$ of them have no savings, while $41.1 \%$ of them have at least $1 \%$ to $10 \%$ of savings, followed by $5.1 \%$ of them with $11 \%$ to $20 \%$ savings, and $1.5 \%$ of them with more than $20 \%$ savings from their monthly income. The assetto-debt ratio reveals that $53.4 \%$, or over half of the respondents claim that their assets are less than their debts. The remaining $23.4 \%$ of them have assets equal to debts, and another $23.2 \%$ of them have assets more than debts. The income adequacy shows that more than half $(53.3 \%)$ of the female-headed households have income enough for basic needs only. Around $29.9 \%$ of them claim that their income is not enough to bear the cost of living, while $9.6 \%$, and $7.2 \%$ of them feel their income is enough for many things, and enough to buy all desired goods, and still they can save. On the savings side, higher percentages of savings or investments are being made in Tabung Haji or Pilgrim Fund Board (29.4\%), Employee Provident Fund (EPF) (22.8\%), and Amanah Saham $(12.3 \%)$.

Table 3: Respondent's Socio-Economic Status ( $\mathrm{n}=527)$

\begin{tabular}{|c|c|c|c|}
\hline Socio-economic & Characteristic & $\mathbf{n}$ & $\%$ \\
\hline \multirow[t]{2}{*}{ Household income } & $\leq \mathrm{RM} 1,500$ (Vulnerable) & 321 & 60.9 \\
\hline & $>$ RM 1,500 (Non-Vulnerable) & 206 & 39.1 \\
\hline \multirow[t]{3}{*}{ Savings percentage } & No savings (Non-Savers) & 276 & 52.3 \\
\hline & $1 \%-10 \%$ & 217 & 41.1 \\
\hline & $11 \%-20 \%$ & 27 & 5.1 \\
\hline
\end{tabular}


Debt-to-asset ratio

Income adequacy

Types of savings / investment
Assets less than debts

Assets equal to debts

Assets more than debts

Not enough

Enough for basic needs only

Enough for many things

Enough to buy all desired goods

$\&$ able to save

Tabung Haji

Employee Provident Fund (EPF)

Cooperative

Amanah shares

Insurance

Shares / Equity

Real estate (House, etc)

Others

$\begin{array}{cc}281 & 53.4 \\ 123 & 23.4 \\ 122 & 23.2 \\ 158 & 29.9 \\ 281 & 53.3 \\ 51 & 9.6 \\ 38 & 7.2 \\ 155 & 29.4 \\ 120 & 22.8 \\ 21 & 4.0 \\ 65 & 12.3 \\ 24 & 4.6 \\ 3 & 0.6 \\ 20 & 3.8 \\ 16 & 3.0\end{array}$

53.4

23.4

29.9

53.3

9.6

7.2

29.4

22.8

4.0

12.3

4.6

3.0

The results from Table 4 below display moderate positive relationships between locus of control $(\mathrm{r}=0.315, \mathrm{p}=0.000)$ and religiosity $(\mathrm{r}=0.225, \mathrm{p}=0.000)$ with life satisfaction. For the personality domains, locus of control is found to have a stronger association than religiosity. Female-headed households with greater locus of control and religiosity may experience greater life satisfaction. Personality in this study alludes to the individual characteristics of Malaysian single mothers, which comprises of religiosity, and locus of control, which influence their life satisfaction. Many prior studies have proven that religiosity contributes to better life satisfaction of individuals by improving health and life expectancy, providing serenity, and reducing stress, depression, and anxiety (Abdel-Khalek, 2010; Williams \& Sternthal, 2007). According to these results, the first and second hypotheses are supported.

Furthermore, there is a weak, and positive association between financial capability, and life satisfaction $(\mathrm{r}=0.159, \mathrm{p}=0.000)$ of female-headed households in Malaysia. This means the higher the financial capability of the female-headed households, the higher the life satisfaction will be. Meanwhile, a higher correlation $(b=0.684, p=0.001)$ was found within the study of Melhuish et al., (2008) among young mothers in America. The difference in correlation may be due to the inclusive economic environments in America, which encourages individuals to be more financially capable, and lead better lives compared to Malaysia. According to this result, the third hypothesis is supported.

However, a weak, and negative relationship is found between financial vulnerability, and life satisfaction $(\mathrm{r}=-0.224, \mathrm{p}=0.000)$ of female-headed households in Malaysia. The result explains that female-headed households with higher financial vulnerability will experience a lower life satisfaction, and vice versa. According to this result, the fourth hypothesis is supported. The results are similar to studies conducted by Melhuish et al., (2008) with 8,000 young mothers in America, as financial strains have moderate associations with depression $(b=0.34, p<0.01)$, and life satisfaction $(b=0.26, p<0.01)$. Financial strain or hardship results in higher levels of chronic stress of single mothers contrasted to married women (Endut, Azmawati, \& Hashim, 2015). Higher debt levels, insufficient income, and a lack of savings are part of financial vulnerability, which affect the economic well-being of an individual, and their overall well-being including retirement confidence and life satisfaction (Sabri \& Aw, 2019). 
Table 4: Pearson's Correlation Matrix

\begin{tabular}{llccccc}
\hline \hline & \multicolumn{1}{c}{ Variable } & $\mathbf{1}$ & $\mathbf{2}$ & $\mathbf{3}$ & $\mathbf{4}$ & $\mathbf{5}$ \\
\hline 1. & Life satisfaction & 1.000 & & & & \\
2. & Locus of control & 0.315 & 1.000 & & & \\
3. & Religiosity & 0.225 & 0.266 & 1.000 & & \\
4. & Financial capability & 0.159 & 0.261 & 0.173 & 1.000 & \\
5. & Financial vulnerability & -0.224 & 0.211 & 0.054 & -0.229 & 1.000 \\
\hline \hline
\end{tabular}

Notes: $\mathrm{p} \leq 0.01$

\subsection{Predictors of Life Satisfaction among Female-Headed Households}

The results of the multiple regression are shown in Table 5, and the model described $15.4 \%$ of the variance in life satisfaction which is predicted significantly by the model $(\mathrm{F}=30.991, \mathrm{p}=0.000)$. Personality is contributing significantly to the model with both domains that are locus of control $(b=0.152, p \leq 0.01)$ and religiosity $(b=0.054, p \leq 0.01)$ significantly influencing life satisfaction. Meanwhile both financial capability $(b=0.023, p \leq 0.01)$, and financial vulnerability $(b=0.040$, $\mathrm{p} \leq 0.01)$ also contributed significantly to the model. The lower value of variance reveals that there is a huge potential that other factors might explain the life satisfaction of female-headed households. Emotional, and psychological aspects predict life satisfaction with a higher variance. For instance, self-esteem, extraversion, openness, conscientiousness, agreeableness, and neuroticism (Joshanloo \& Afshari, 2011) factors explained 25.4\% of variance, perceived negative stress, positive stress and resilience (Abolghasemi \& Varaniyab, 2010) with 31.3\%, and professional status, emotional exhaustion, and personal accomplishment (Lee, Hwang, Kim, \& Daly, 2004) with $30 \%$ of variance.

Significant beta values at the 0.01 level in Table 5 revealed noteworthy determinants among the factors to explain the dependent variable. Among them, financial vulnerability is the strongest determinant $(\beta=0.203$ ) of life satisfaction followed closely by locus of control $(\beta=0.202)$. Thus, by comparing the beta coefficients, financial capability $(\beta=0.128)$ is the least contributor towards life satisfaction while religiosity $(\beta=0.138)$ as the other personality domain is the third strongest determinant. Between the two domains of personality, locus of control is found as a stronger determinant as compared to religiosity which means that locus of control is more important than religiosity in determining satisfaction in life. According to these results, the fifth hypothesis was supported.

Financial vulnerability is the strongest predictor of life satisfaction found in this study among Malaysian female-headed households. Financial vulnerability is strongly linked to lower life satisfaction among female-headed households due to their sole responsibility over the households' financial needs (Pollmann-schult, 2016). The feeling of anxiety, and worry about not having sufficient funds to meet an individual's needs does not only affect their well-being, but can also diminish their productivity, and functionality. Many individuals are aware of long-term financial planning, but due to financial difficulties, they choose instead to concentrate on fulfilling immediate needs before planning for the future (Arashiro, 2011). Eventually, such households' financial sustainability during financial shocks becomes uncertain.

The strong influence of personality on subjective well-being is seen as one of the most replicable, and most surprising findings to emerge from the last four decades (Garcia, 2011). In the present 
study, personality consists of religiosity, and locus of control as domains in influencing life satisfaction of female-headed households. Religiosity consistently has been reported in enhancing better health, higher levels of life satisfaction, lower stress, and depression (Abdel-Khalek, 2010). Besides that, one of the fundamental impacts of locus of control on subjective well-being is the manner by which it influences coping strategies (Brandtstädter \& Baltes-Götz, 1990). Thus, the two domains under personality provide a sense of positive emotions, leading to better coping mechanisms in leading a life.

According to the results, those with higher financial capability demonstrate greater life satisfaction. Financial capability impacts a person's financial behaviour, like how they manage money, and issues related to finance. It only requires financial knowledge, self-efficacy, and skills to implicate monetary management decisions that best fit for the existence conditions. Good financial behaviour improves financial well-being, and increases the financial security of consumers (Abdullah, Sabri \& Muhammad Arif, 2019; Ahmad, Sabri, Abd Rahim, \& Osman, 2016; Falahati \& Sabri, 2015). Additionally, a positive attitude towards money for example, retention, and good money attitude enable the person to deal with their finances via budgeting, strengthening their endeavors to produce income to ensure their future monetary requirements (Sabri \& Zakaria, 2015). Apart from that, a financially capable person also can take advantage of financial inclusion as they are able to stay informed, choose right products, manage their money, and plan ahead, leading them to increase their well-being in the future. Higher financial capability enables individuals to reduce their financial stress, and subsequently leads to a better subjective well-being.

Table 5: Multiple Regression Results for Determinants of Life Satisfaction Among Female-Headed Households

\begin{tabular}{lcccc}
\hline \multicolumn{1}{c}{ Variable } & B & Beta $(\boldsymbol{\beta})$ & t & Sig. \\
\hline (Constant) & 2.115 & & 2.156 & 0.032 \\
Locus of control & 0.152 & 0.202 & 4.548 & 0.000 \\
Religiosity & 0.054 & 0.138 & 3.304 & 0.001 \\
Financial capability & 0.023 & 0.128 & 2.926 & 0.004 \\
Financial vulnerability & 0.040 & 0.203 & -4.712 & 0.000 \\
\hline \hline
\end{tabular}

Notes: $\mathrm{R}=0.401 ; \mathrm{R}^{2}=0.161 ;$ Adjusted $\mathrm{R}^{2}=0.154 ; \mathrm{F}=24.964 ;$ Sig. $\mathrm{F}=0.000 ; \mathrm{p} \leq 0.01$

\section{CONCLUSION}

Majority of the single mothers in Malaysia were above 51 years old, and the mean age is 53.14 years, and therefore it is clear that most of the Malaysian single mothers will be reaching to the retirement phase of life. Further, higher percentage of single mothers were Bumiputera Muslims, and more than $50 \%$ of they completed their education level only up to secondary level. Therefore, most of them were self-employed, and the income adequacy of almost half of the respondents were enough for basic needs only. More training, and development can be implemented in terms of money management, and financial education courses, which might be helpful for the femaleheaded households to cope with the rising living costs, and ease their financial burden through being the only breadwinner of their respective households. The result also indicated that the locus of control, religiosity, financial capability, and financial vulnerability are significant determinants 
of Malaysian female-headed households' financial vulnerability, and the $15.4 \%$ of the variance in financial vulnerability was explained by the regression model.

Although the female-headed households show a moderate level of financial vulnerability and, financial capability, there is room for improvement for certain issues like diversifying their retirement funds, and savings into a few more investment options. Depending on welfare, part time jobs, and entrepreneurship might help to increase their income; at the same time, investments will help their incomes grow. A better understanding, and involvement in the modern financial system, and financial instruments is important for single mothers, to secure their financial future, and achieve improved life satisfaction as a whole.

\section{IMPLICATIONS OF THE STUDY}

One of the main beneficiaries from this study is the female-headed households themselves as it will be useful for self-realization, and to make improvements towards a better life. More care should be given to enhance their self-confidence, and having more control over themselves rather than depending too much on other people when it comes to decision-making. The KPWKM has been working on enhancing the welfare of female-headed households in Malaysia by various programmes for example, $\mathrm{i}$-Kit which gives training in terms of handicraft making, and basic entrepreneurship; jejari bestari which focuses on tailoring, welfare funds for children of single mothers and one-off grants worth RM 2,700 (KPWKM, 2014).

Besides, single-mother associations play a huge role in being the main support system for the female-headed households. More personality-building, and counseling sessions could be held by the associations to help build the confidence of single mothers. This will help the single mothers to have better self-esteem, and develop the attitude of trying new things as well as train them to be a risk-taker. In addition, more activities related to finance should be prioritized by the associations in collaboration with the Counseling, and Debt Management Agency (AKPK), local banks as well as investment companies to improve their financial capability, and financial vulnerability. This will provide them with better financial practices using the right financial tools, financial skills, and necessary financial products and services, which will benefit them on the long run.

Furthermore, financial institutions such as banks, and investment companies have some role to play dependent on the results of this research. The study reveals that most for the female-headed households are dependent on Employee Provident Fund (EPF) for retirement, and there is less diversification on their retirement fund. Thus, banks, and investment companies have the responsibility, and accountability to promote, and encourage other types of investments, and savings to the respondents to lower the risk of investment. Furthermore, this study also revealed that fewer respondents consider Insurance, Shares, and cooperatives as a source of investment. Hence, more exposure to investment plans or policies can be developed according to the needs and financial capabilities of this community in order to encourage them to participate in the capital market frequently. 


\section{LIMITATIONS AND RECOMMENDATIONS FOR FUTURE STUDIES}

The required sample size for the population of 235,000 single mothers throughout Malaysia was selected using multi-stage random sampling. Thus, out of 14 states in Malaysia, only five states were selected as the sample, and the survey was limited due to limitations on budget, and time. In future studies, by increasing the number of states, more generalized data can be obtained. It also can be used for comparative studies on female-headed households between states of Malaysia, and more issues related to female-headed households can be catered for specifically.

Besides, the aspect of geography can be considered in future research. Researchers can compare the differences in personality domains, financial vulnerability, financial capability, and life satisfaction between urban and rural female-headed households. The current study could not compare these as the data was not balanced. More specific results on the requirements of single mothers can be obtained by comparing urban and rural aspects, and different approaches of solutions or implications can be suggested to enhance the life satisfaction.

Finally, more variables should be discovered in future studies to add knowledge regarding this topic. Although subjective measures offer better explanation to understand life satisfaction, objective measurements such as (1) retirement planning, (2) financial health, (3) financial inclusion, or (4) financial sustainability can be included in future studies related to life satisfaction among Malaysian single mothers.

\section{REFERENCES}

Abdel-Khalek, A. M. (2010). Quality of life, subjective well-being, and religiosity in Muslim college students. Quality of Life Research, 19(8), 1133-1143. doi:10.1007/s11136-010$9676-7$.

Abdullah, N., Sabri, M.F., \& Muhammad Arif, A.M. (2019). The relationship between attitude towards money, financial literacy and debt management with young worker's financial well-being. Pertanika Journal of Social Science and Humanities, 27(1), 361-378.

Abolghasemi, A., \& Varaniyab, T. S. (2010). Resilience and perceived stress: Predictors of life satisfaction in the students of success and failure. Procedia - Social and Behavioural Sciences, 5(2), 748-752. doi:10.1016/j.sbspro.2010.07.178.

Achour, M., Grine, F., Mohd Nor, M. R., \& Yusoff, M. Y. Z. (2015). Measuring religiosity and its effects on personal well-being: A case study of Muslim female academicians in Malaysia. Journal of Religion and Health, 54(3), 984-997. doi:10.1007/s10943-014-9852-0.

Afifi, T. O., Cox, B. J., \& Enns, M. W. (2006). Mental health profiles among married, nevermarried, and separated/divorced mothers in a nationally representative sample. Social psychiatry and psychiatric epidemiology, 41(2), 122-129. doi:10.1007/s00127-005-00053.

Ahmad, S. Y., \& Sabri, M. F. (2015). Financial security of female-headed households: A Preliminary Study. Asian Journal of Social Sciences \& Humanities , 4(4), 219-228.

Ahmad, S. Y., Sabri, M. F., Abd Rahim, H., \& Osman, S. (2016). Mediating effect of self-coping mechanisms on associations between financial practices and financial security of femaleheaded households. Malaysian Journal of Consumer and Family Economics, 19, 143160. 
Aldana, S. G., \& Liljenquist, W. (1998). Validity and reliability of a financial strain survey. Financial Counseling and Planning, 9(2), 11-19.

Al-Goaib, S. (2003). Religiosity and social conformity of university students: An analytical study applied at King Saoud University. Arts Journal of King Saoud University, 16(1), 51-99.

Arashiro, Z. (2011). Negotiating the free trade area of the Americas. United States: Palgrave Macmillan

Atkinson, A. McKay, S. Kempson, E. \& Collard, S. (2006). Levels of financial capability in the UK. Results of a baseline survey. Bristol: University of Bristol. Retrieved August 28, 2019 from: http://www.fsa.gov.uk/pubs/consumer-research/crpr47.pdf.

Baharudin, R., Krauss, S. E., Yacoob, S. N., \& Pei, T. J. (2011). Family processes as predictors of antisocial behaviours among adolescents from urban, single-mother Malay families in Malaysia. Journal of Comparative Family Studies, 42(4), 509-522.

Booth, A., \& Amato, P. (1991). Divorce and psychological stress. Journal of Health and Social Behaviour, 32(4), 396-407. doi:10.2307/2137106.

Brandtstädter, J., \& Baltes-Götz, B. (1990). Personal control over development and quality of life perspectives in adulthood. Successful Aging: Perspectives From The Behavioural Sciences, 197-224.

Bull, T., \& Mittelmark, M. B. (2009). Work life and mental wellbeing of single and non-single working mothers in Scandinavia. Scandinavian Journal of Public Health, 37(6), 562-568. doi: 10.1177/1403494809340494.

Canady, R. B., \& Broman, C. (2003). Marital disruption and health: Investigating the role of divorce in differential outcomes. Sociological Focus, 36(3), 241-255. doi:10.1080/0038 0237.2003.10570726.

Choi, L. (2009). Financial stress and its physical effects on individuals and communities. Community Development Investment Review, 5(3), 120-122.

Chou, K., \& Chi, I. (2002). Financial strain and life satisfaction in Hong Kong elderly Chinese: Moderating effect of life management strategies including selection, optimization, and compensation. Aging \& Mental Health, 6(2), 172-177. doi:10.1080/13607860220126781.

Diener, E. D., Emmons, R. A., Larsen, J., \& Griffin, S. (1985). The satisfaction with life scale. Journal of Personality Assessment, 49(1), 71-75.

Economic Planning Unit (EPU) (2015). Eleventh Malaysia plan, 2016-2020: Anchoring growth on people. Pencetakan Nasional Malaysia Berhad.

Endut, N., Azmawati, A. A., \& Hashim, I. H. M. (2015). Formal and informal support systems for single women and single mothers in Malaysia. SHS Web of Conferences, 18, 1-9. doi:10.1051/shsconf/20151803002.

Faizah, A., \& Azian, A. (2013). Profile of single mothers in southern Malaysia and issues afflicting their lives. British Journal of Arts and Social Sciences, 16(1), 197-206.

Faizah, G., \& Hashim, H. B. (2013). Challenges and locus control among single mothers in Muar, Johor. Journal of Emerging Trends in Educational Research and Policy Studies, 4(5), 760-765.

Falahati, L., \& Sabri, M. F. (2015). An exploratory study of personal financial well-being determinants: Examining the moderating effect of gender. Asian Social Science, 11(4), 33-42.

Financial Services Authority (FSA) (2006). Financial Capability in the UK: Establishing a Baseline. Retrieved from http://doc.ukdataservice.ac.uk/doc/5697/mrdoc/pdf $/ 5697$ baseline.pdf. 
Firth, L., Mellor, D. J., Moore, K. A., \& Loquet, C. (2004). How can managers reduce employee intention to quit? Journal of Managerial Psychology, 19(2), 170-187. doi:10.1108/02683 940410526127.

Frey, B. S., \& Stutzer, A. (2002). What can economists learn from happiness research? Journal of Economic Literature, 40(2), 402-435. doi:10.1257/002205102320161320.

Garcia, D. (2011). Two models of personality and well-being among adolescents. Personality and Individual Differences, 50(8), 1208-1212. doi:10.1016/j.paid.2011.02.009.

Hamid, T., Mottan, J., \& Tyng, S. (2010). Keluarga induk tunggal: Penekanan kepada cabaran keluarga ibu tunggal. Keluarga dan Keibubapaan ( $3^{\text {rd }}$ Ed.). Selangor: Universiti Putra Malaysia.

Hashim, I. H. M., Azmawati, A. A., \& Endut, N. (2015). Stress, roles and responsibilities of single mothers in Malaysia. SHS Web of Conferences, 18, 1-8.

Hosseinkhanzadeh, A. A., \& Taher, M. (2013). The relationship between personality traits with life satisfaction. Sociology Mind, 3(1), 99-105.

Huber, S., \& Huber, O. W. (2012). The Centrality of Religiosity Scale (CRS). Religions, 3, 710724. doi: 10.3390/rel3030710.

Ishak, D., Selvaratnam, D. P., \& Idris, N. A. (2009). Isu dan cabaran ibu tunggal dalam menghadapi perubahan persekitaran global. Prosiding PERKEM Iv, 1, 324-336.

Joshanloo, M., \& Afshari, S. (2011). Big Five Personality Traits and self-esteem as predictors of life satisfaction in Iranian Muslim University students. Journal of Happiness Studies, 12(1), 105-113. doi:10.1007/s10902-009-9177-y.

Klasen, S., Lechtenfeld, T., \& Povel, F. (2011). What about the women? Female headship, poverty and vulnerability in Thailand and Vietnam. Discussion Papers No 76. Göttingen: Courant Research Centre: Poverty, Equity and Growth (CRC-PEG) in Developing and Transition Countries, University of Göttingen.

Klonowicz, T. (2001). Discontented people: reactivity and locus of control as determinants of subjective well-being. European Journal of Personality, 15(1), 29-47. doi:10.1002/per.387.

Lee, H., Hwang, S., Kim, J., \& Daly, B. (2004). Predictors of life satisfaction of Korean nurses. Journal of Advanced Nursing, 48(6), 632-641. doi:10.1111/j.1365-2648.2004.03251.x.

Loke, Y. J. (2017). Financial vulnerability of working adults in Malaysia. Contemporary Economics, 11(2), 205-218.

Lucas, R. (2005). International migration and economic development: Lessons from low-income countries. Canadian Studies in Population, 39(1-2), 151-153.

Mahal, A., Seshu, M., Mane, S., \& Lal, S. (2012). Old age financial security in the informal sector: Sex work in India. Journal of South Asian Development, 7(2), 183-202. doi:10.1177/ 0973174112466433.

Melhuish, E., Belsky, J., \& Malin, A. (2008). An investigation of the relationship between financial capability and psychological well-being in mothers of young children in poor areas in England. Financial Services Authority (FSA) Occassional Paper Series 30. London: Institute Studies of Children, Families, and Social Issues, Birkbeck College, University of London.

Ministry of Women Family and Community Development (KPWKM) (2014). Pelan tindakan pemerkasaan ibu tunggal 2015-2020. Putrajaya.

Mirowsky, J., \& Ross, C. E. (2004). Education, social status, and health. Canadian Journal of Sociology Online, 3, 242-245. 
Moga Dass, T., \& Sabri, M. F. (2017). The Financial Status and Factors Affecting Personal WellBeing Among Urban Poor in Kuala Lumpur. Malaysian Journal of Social Sciences and Humanities, 2(1), 21-39.

Organisation for Economic Co-operation and Development (OECD) (2011). How's life?: Measuring well-being. OECD Publishing.

Organisation for Economic Co-operation and Development (OECD) (2016). OECD economic surveys (November). OECD Publishing.

Pettijohn, T. F., Pettijohn, T. F., \& Sacco, D. F. (2005). A locus of control measure as a teaching demonstration. Psychological Reports, 97(2), 666-666. doi:10.2466/pr0.97.2.666-666

Pollmann-Schult, M. (2016). Single Motherhood and Life Satisfaction in Comparative Perspective: Do Institutional and Cultural Contexts Explain the Life Satisfaction Penalty for Single Mothers? Journal of Family Issues, 39(7), 2061-2084. doi:10.1177/0192513X177411 78.

Rotter, J. B. (1966). Generalized expectancies for internal versus external control of reinforcement. Psychological monographs: General and applied, 80(1), 1-28. doi: $10.1037 /$ h0092976.

Sabri, M. F., Abdullah, N., Zenhendel, M., \& Ahmad, S.Y. (2017). Moderation effect of gender on financial literacy, money attitude, financial strains and financial capability. Malaysian Journal of Consumer and Family Economics, 20, 83-101.

Sabri, M. F., \& Aw, E. C. X. (2019). Financial literacy and related outcomes: The role of financial information sources. International Journal of Business \& Society, 20(1), 286-298.

Sabri, M. F., Mokhtar, N., Ho, C. S. F., Anthony, M., \& Wijekoon, R. (2020). Effects of gender and income on Malaysian's financial capability. Malaysian Journal of Consumer and Family Economics, 24, 124-152.

Sabri, M. F., \& Zakaria, N. F. (2015). The Influence of financial literacy, money attitude, financial strain and financial capability on young employees' Financial Well-being. Pertanika Journal of Social Sciences \& Humanities, 23(4), 827-848.

Schaffer, H. R. (1996). Social development. Oxford: Blackwell Publishing.

Sharif, S. P. (2017). Locus of control, quality of life, anxiety, and depression among Malaysian breast cancer patients: The mediating role of uncertainty. European Journal of Oncology Nursing, 27, 28-35. doi:10.1016/j.ejon.2017.01.005.

Starkey, A. J., Keane, C. R., Terry, M. A., Marx, J. H., \& Ricci, E. M. (2013). Financial distress and depressive symptoms among African American Women: identifying financial priorities and needs and why it matters for mental health. Journal of Urban Health, 90(1), 83-100. doi:10.1007/s11524-012-9755-x.

Suhail, K., \& Chaudhry, H. R. (2004). Predictors of subjective well-Being in an Eastern Muslim Culture. Journal of Social and Clinical Psychology, 23(3), 359-376.

Taylor, M. (2011). Measuring Financial Capability and its Determinants Using Survey Data. Social Indicators Research, 102(2), 297-314. doi:10.1007/s11205-010-9681-9.

Taylor, M., Jenkins, S., \& Sacker, A. (2009). Financial capability and wellbeing: Evidence from the BHPS. Occasional Papers in Financial Regulation, 34(May), 1-98.

Tiliouine, H., \& Belgoumidi, A. (2009). An exploratory study of religiosity, meaning in life and subjective wellbeing in Muslim students from Algeria. Applied Research in Quality of Life, 4(1), 109-127. doi:10.1007/s11482-009-9076-8.

Wan, C. K., Jaccard, J., \& Ramey, S. L. (1996). The relationship between social support and life satisfaction as a function of family structure. Journal of Marriage and the Family, 58(2), 502-513. doi:10.2307/353513. 
Williams, D. R., \& Sternthal, M. J. (2007). Spirituality, religion and health: Evidence and research directions. Medical Journal of Australia, 186(10), 47-50. doi:10.1080/19349637.2011. 616080.

\section{APPENDIX}

Appendix 1: Instrument

\begin{tabular}{ll}
\hline \hline Item & Statement \\
\hline \multicolumn{2}{l}{ Locus of Control } \\
1 & I usually get what I want in my life \\
2 & I need to be kept informed about news event \\
3 & People must be the master of their fate \\
4 & I never try anything that I am not sure of \\
5 & I earn the respect and honours I receive \\
6 & Other people usually control my life \\
7 & A person can get rich by taking risks \\
8 & Persistence and hard work usually lead to success \\
9 & The success I have is largely a matter of chance \\
\hline
\end{tabular}

\section{Religiosity}

1 Think about religious issues

2 Take part in religious activities

$3 \quad$ How often do you pray?

$4 \quad$ How often do you read the Holy Book or other religious literature?

5 I feel thankful for my blessings

6 I ask for God's help in the midst of daily activities

7 I feel guided by God in the midst of daily activities.

8 I find strength in my religion or spirituality

$9 \quad$ I find comfort in my religion or spirituality

\section{Financial Capability}

$1 \quad$ I make plans for my expenses

2 I pay my bills on time

3 I review and evaluate my expenses

4 I regularly set money aside for possible unexpected expenses (car repairs, school costs, health bills)

5 I set specific financial goals and strive to achieve them

6 I regularly monitor financial indicators such as changes in the housing market, stock market and interest rates

7 I actively seek financial information through professional advice

8 I frequently keep up to date with financial products

9 I am always interested to learn to make comparisons in financial services offered

10 I would like to know futher about financial issues and learn how to interpret the information

11 I considered several produts/loans/policies/accounts from different companies before making my decision

12 I have read the terms and conditions in detail before agreeing / signing 
13 I understand about the various financial products that I need without consulting a financial advisor

14 I believe financial advisers and accept what they recommend

15 I compare products on features and price rather than making a choice based on brand image

16 I make adequate provision for unexpected expenses (shrinking income)

17 I make financial provision for retirement

18 I prefer to have a good standard of living today than planning for retirement

19 Household income after retirement are able to guarantee my life more comfortable

20 Apart from contributing in pension funds, it is important for me to make my own savings

\section{Financial Vulnerability}

$1 \quad$ Unable to save monthly

2 I don't have sufficient money for emergency purposes

3 Income received is insufficient

$4 \quad$ My job does not gives any guarantee

5 I suffer from depression due to lack of money

6 I'm sick worrying about personal / family expenses

$7 \quad$ My current financial situation makes me more anxious

8 Unable to concentrate on work due to financial problems

9 Depending on the part time work, overtime, commission / bonus to finance the cost of living

10 Delay in paying my utility bills (water, electricity, telephone)

11 Borrows money to buy household necessities

12 Borrowing money from loan sharks

13 Unable to pay rental or other accruals

14 I don't have sufficient money for medical expenses

15 Paying debts left by my late / ex-husband husband

16 Receiving financial aid from the family of my late / ex-husband 